\title{
Unsaturated geotechnics applied to geoenvironmental engineering problems involving geosynthetics
}

\author{
Abdelmalek Bouazza ${ }^{\text {a,* }}$, Jorge Zornberg ${ }^{\text {b, }}$, John S. McCartney ${ }^{c, 2}$, Rao M. Singh ${ }^{\text {a,3 }}$ \\ ${ }^{a}$ Monash University, Department of Civil Engineering, Bldg. 60, Melbourne, Vic. 3800, Australia \\ b The University of Texas at Austin, Civil Engineering Department-GEO, 1 University Station C1792 Austin, TX 78712-0280, USA \\ c University of Colorado Boulder, Department of Civil, Environmental, and Architectural Engineering, UCB 428, Boulder, CO 80309, USA
}

\section{A R T I C L E I N F O}

\section{Article history:}

Accepted 6 November 2012

Available online 15 February 2013

\section{Keywords:}

Capillary break

Desiccation

Flow

Geosynthetics

Interface shear strength

Unsaturated

\begin{abstract}
A B S T R A C T
Movement of fluids in the unsaturated zone plays an important role in many geoenvironmental engineering problems. Examples include cover and basal liner systems for waste containment facilities where geosynthetics are widely used, amongst many other examples. This paper highlights the importance of assessing the unsaturated characteristics of geosynthetics and their influence on the behaviour of engineered systems where soils and geosynthetics interact under unsaturated conditions. It includes information on the water retention curve and hydraulic conductivity function of geosynthetics such as geotextiles and geosynthetic clay liners (GCLs) with particular focus on capillary barriers, liner performance under elevated temperatures, and interface friction respectively. Mechanisms involved in the development of capillary barriers are evaluated to explain the storage of water at the interface between materials with contrasting hydraulic conductivity (e.g. a fine-grained soil and a nonwoven geotextile). Potential desiccation of GCLs is explained in the light of an application in a liquid waste impoundment.
\end{abstract}

(C) 2013 Elsevier B.V. All rights reserved.

\section{Introduction}

Geosynthetics are defined as planar products manufactured from polymeric materials, which are used with soil, rock or other geotechnical engineering related material as an integral part of a man-made project, structure, or system (ASTM, 1995). There are significant number of geosynthetic types and geosynthetic applications in geotechnical and geoenvironmental engineering (Bouazza et al., 2002). They can be used to fulfill most of the geosynthetics functions including containment as part of the liner systems of landfills and mining containment facilities and soil remediation, these functions can include:

- Separation: the material is placed between two dissimilar materials so that the integrity and functioning of both materials can be maintained or improved,

- Reinforcement: the material provides tensile strength in materials or systems that lacks sufficient tensile capacity,

- Filtration: the material allows flow across its plane while retaining the fine particles on its upstream side,

\footnotetext{
* Corresponding author. Tel.: +6139905 4956.

E-mail addresses: malek.bouazza@monash.edu (A. Bouazza), zornberg@mail.utexas.edu (J. Zornberg), john.mccartney@colorado.edu (J.S. McCartney), rao.singh@monash.edu (R.M. Singh).

1 Tel.: + 15122323595 .

2 Tel.: +13034920492.

3 Tel.: +6139905 4981 .
}

- Drainage: the material transmits fluid within the plane of their structure,

- Hydraulic/gas barrier: the material is relatively impervious and its sole function is to contain liquids or gasses, and

- Protection: the material provides a cushion above (or below) geomembranes in order to prevent damage by punctures during placement of overlying materials.

Geosynthetics may also serve multiple functions, in this case two or more individual materials are laminated, bonded or needle punched together. They are referred to as geocomposites and are used in drainage of fluids or waterproofing applications amongst others applications.

In most cases, geosynthetics are placed above the groundwater table where soils are under unsaturated conditions. Engineering properties of unsaturated earthen systems combining soils and geosynthetics can be significantly influenced by the water storage characteristics of both the soil and the geosynthetic component. Exacerbating the problem further is the hydrophobicity of geosynthetics due to their manufacturing process. When embedded in soils, they can influence significantly the movement of water and give rise to a redistribution of the water content profile. Furthermore, it is well known that the principles of water flow through unsaturated geomaterials (i.e., soils or geosynthetics) are more complex than those for water through saturated media. This is partly because the most important variable that governs the rate of water flow through geomaterials (i.e., the hydraulic conductivity) is not constant with 
varying water content. Instead, the hydraulic conductivity under unsaturated conditions varies with the level of water content (or suction) within the geomaterial. Consequently, relative amounts of water and air in the geomaterial highly influence its hydraulic behaviour. Key to the understanding of this phenomenon is the assessment of water flow and storage in porous geomaterials (e.g., soils, geosynthetics) under unsaturated conditions.

This paper includes an evaluation of the hydraulic properties of geosynthetics under unsaturated conditions that are relevant to waste containment liners. These properties include the water retention curve and the hydraulic conductivity function and will focus particularly on porous geosynthetics and geocomposite materials. Specific applications are discussed to illustrate new opportunities that may result from a better understanding of the unsaturated hydraulic properties of geosynthetics. Finally, linkages between the unsaturated hydraulic properties of geosynthetics and soils and their mechanical interface behaviour are discussed.

\section{Hydraulic properties of unsaturated geotextiles}

Among the various types of geosynthetics, geotextiles have been used in geotechnical and geoenvironmental engineering applications to fulfill the widest range of functions (Bouazza et al., 2002; Koerner, 2005; Zornberg and Christopher, 2007). This includes separation between different soil layers and filtration and drainage from surrounding soil amongst many other functions. Geotextiles are able to meet these requirements despite their small thickness (e.g., $2.5 \mathrm{~mm}$ ) partly due to their high porosity (typically about 0.9 ), which is greater than that of most soils. Geotextiles have a uniform pore size compared to most soils (Palmeira and Gardoni, 2002; Aydilek et al., 2007). There are two types of geotextiles: woven geotextiles and nonwoven geotextiles. Woven geotextiles are manufactured using traditional weaving methods and are extensively used for reinforcement purposes. Nonwoven geotextiles are manufactured by needle punching or melt bonding and are extensively used for drainage, filtration, protection, and separation.

The water storage of soil and geosynthetics is typically quantified using the relationship between volumetric water content and suction, referred to as the Water Retention Curve (WRC). Fig. 1 shows the WRCs for different geotechnical materials. The coarser materials (sand and geotextile) show a highly nonlinear response, with a significant decrease in water content (or degree of saturation) within a comparatively narrow range of suction. The fine-grained soil shows instead a more gradual decrease in water content with increasing suction. The nonlinearity observed in these relationships is partly caused by the range of pore size distributions in these materials.

The WRC for a given material is not only sensitive to the pore size distribution, but also to the soil mineralogy (for the case of soils), polymeric material (for the case of geosynthetics), density, and pore

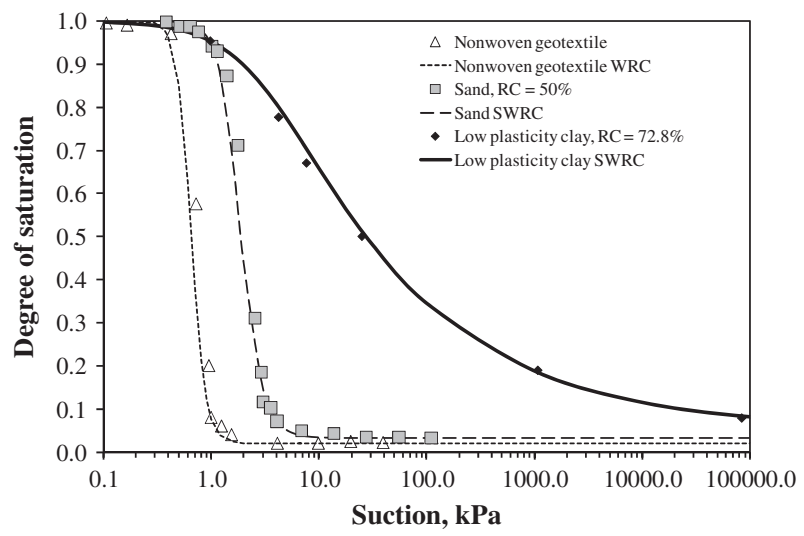

Fig. 1. Typical WRCs for different geotechnical materials (after McCartney et al., 2005). structure (Hillel, 1998; Bouazza et al., 2006a, 2006b). The WRC can show significantly different wetting and drying paths, a phenomenon referred to as hysteresis (Topp and Miller, 1966; Kool and Parker, 1987; Bouazza et al., 2006a). During drying, the largest pores drain first, followed by the smaller pores. During wetting, the smaller pores fill first, but the presence of large pores may prevent some of the small pores from filling. Also, wetting of a dry geomaterial often leads to entrapment of air in the larger pores, preventing saturation of the media unless positive pressure is applied to the water. Air entrapment causes the wetting path to be relatively flat for high suction, with a steep increase in volumetric water content at lower suctions. Fig. 2 shows the WRC of three geotextiles illustrating the significant hysteresis in their response to wetting and drying (Bouazza et al., 2006b). Recent experimental results highlighted also the impact on hysteresis of the direction of flow measurement (Nahlawi, 2009). In particular, it was found that the volumetric water content of geotextiles along the cross-plane direction differed from that obtained along the in-plane direction for the same suction head. Several techniques have been developed to determine experimentally the WRC of soils (Klute, 1986; Wang and Benson, 2004). These techniques have been recently adapted to obtain experimentally the WRC of geotextiles. Two main groups of techniques that have been used to define the WRC include physical techniques and thermodynamic techniques; these have been summarized in details in Zornberg et al. (2010). The reader is referred to this reference for further information.

The WRC of geomaterials is typically quantified by fitting experimental data to power law, hyperbolic, or polynomial functions (Brooks and Corey, 1964; van Genuchten, 1980; Fredlund and Xing, 1994). Although the Brooks and Corey (1964) model is able to represent a sharp air entry suction, the van Genuchten (1980) model has been most commonly used in numerical analyses because it is differentiable for the full suction range. The van Genuchten (1980) model is given by:

$\theta=\theta_{\mathrm{r}}+\left(\theta_{\mathrm{s}}-\theta_{\mathrm{r}}\right)\left[1+(\alpha \psi)^{\mathrm{N}}\right]^{-\left(1-\frac{1}{\mathrm{~N}}\right)}$

where $\theta_{\mathrm{r}}$ is the residual water content, $\theta_{\mathrm{S}}$ is the saturated water content (porosity), and $\alpha$ (units of $\mathrm{kPa}^{-1}$ ) and $\mathrm{N}$ (dimensionless) are fitting parameters. Preliminary estimates of the WRC have been obtained using databases that rely on the granulometric distribution of soils (Fredlund and Xing, 1994). The functions used to fit experimental data from WRC have also been proven to be useful for the case of geotextiles (Bouazza et al., 2006b; Nahlawi et al., 2007).

The relationship between hydraulic conductivity and suction, also referred to as the $K$-function, provides a measure of the increased impedance to water flow with decreasing water content. Conventional methods used to define the $K$-function may be costly, time consuming, and prone to error due to experimental issues involved in the control of

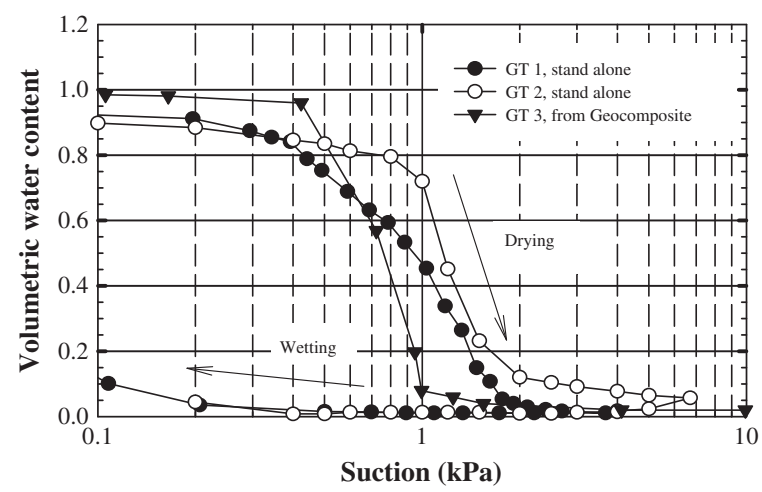

Fig. 2. Geotextile water retention curves. 
water flow through unsaturated geomaterials. Accordingly, $K$-functions (e.g. such as those in Figure 3) are often predicted based on the information obtained using theoretical derivations based on the measured WRC. Specifically, the $K$-function obtained using the parameters from the van Genuchten-Mualem model (van Genuchten, 1980). Other predictive relationships for the $K$-function are given by Burdine (1953), Brooks and Corey (1964) and Fredlund and Xing (1994) among others. Nahlawi et al. (2007) noted that the $K$-functions for geotextiles were better estimated by the van Genuchten WRC equation because it is continuous. It is interesting to note from Fig. 3 that the predictive hydraulic conductivity functions indicate that the three geotextiles require suctions between $0.8 \mathrm{kPa}$ and $1.2 \mathrm{kPa}$ to induce a rapid drop in hydraulic conductivity. This indicates that the geotextiles will be able to drain/filter water at very low suctions (i.e., less than $1.2 \mathrm{kPa}$ ), whereas an increase in suction will result very rapidly in a much lower water drainage/filter capacity. The partially saturated condition of geotextiles under relatively low suction has important implications to the hydraulic performance of geotextiles. A consequence of low hydraulic conductivity of the geotextile is the creation of a capillary barrier which can be beneficial if it was designed with this intention in mind. However, if the inclusions of geotextiles reduce the ability for moisture to migrate as planned; then they may not be accomplishing their intended purpose and, could even worsen rather than improve the earth system performance. Iryo and Rowe (2005) noted that the formation of geosynthetic capillary barrier may lead to unexpected behaviour in the leak-detection or secondary leachate collection system below a landfill composite liner. They concluded that the time at which leakage occurs from primary landfill liner systems may be seriously overestimated.

\section{Geotextiles and unsaturated soils}

Many design applications involving earth structures have geotextiles placed in contact with unsaturated soils, in some cases for much of their design life. In this respect, quantification of the hydraulic performance of the geotextiles and their interaction with the surrounding soils is crucial to the serviceability and maintenance of these structures. Equally important is the assessment of the unsaturated hydraulic characteristics of the soils in direct contact with the geotextiles. Considering the differences in both materials, it should be expected that their unsaturated hydraulic properties to affect the overall hydraulic performance of earthen systems because of the possible redistribution of the water content profile.

Two soils were used in the testing program reported by McCartney et al. (2005), Bouazza et al. (2006b) and Zornberg et al. (2010). A low plasticity clay was used as a relatively low hydraulic conductivity material $\left(k_{s}=1.23 \times 10^{-6} \mathrm{~m} / \mathrm{s}\right)$. For all tests, the clay was statically compacted to a relative compaction of $75 \%$ in relation to the maximum dry density of $1902 \mathrm{~kg} / \mathrm{m}^{3}$. A coarse sand was used for comparison with a geosynthetic drainage layer as it has a high hydraulic conductivity

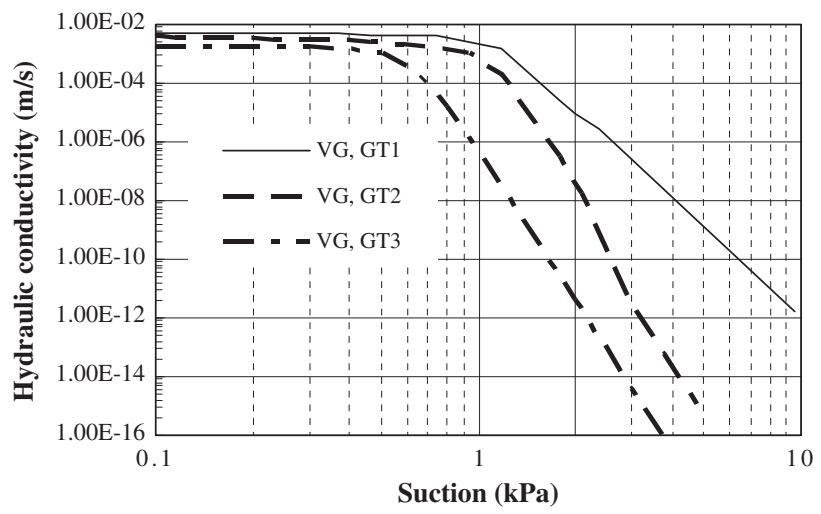

Fig. 3. Hydraulic conductivity functions of different geotextiles.
( $k_{s}=5.3 \times 10^{-4} \mathrm{~m} / \mathrm{s}$ ), representative of conventional drainage layers. In all tests, the sand was placed at a void ratio corresponding to a relative density of $50 \%\left(e_{\max }=0.78, e_{\min }=0.56\right)$. Coarse gravel with high hydraulic conductivity $\left(k_{s}=1.3 \times 10^{-4} \mathrm{~m} / \mathrm{s}\right)$ was used as a foundation layer. The geocomposite drainage layer used in this study consists of a geonet sandwiched between two nonwoven geotextiles $\left(k_{S G T}=\right.$ $1.93 \times 10^{-3} \mathrm{~m} / \mathrm{s}$ ). The grain size distribution for the clay and sand are shown in Fig. 4, along with the apparent opening size (AOS) of the nonwoven geotextile component (GT3) of the geocomposite material. This figure indicates that the clay material has a wide range of particle sizes and should retain significant volume of water even when unsaturated. The sand is poorly graded, with a large fraction of coarse particles, suggesting that it will drain rapidly. According to Carroll's criterion $\left(\right.$ AOS $<2.5 \mathrm{~d}_{85}$ ), the geotextile is an acceptable filter for both the silt and the sand (Koerner, 2005).

Although the study involved infiltration into dry soil following the wetting-path of the soil water retention curve, the drying-path defined in their work can still be used to highlight important hydraulic differences between the materials. Fig. 5 shows the water retention data of the three materials along with the best-fit water retention curves defined using the SWRC model proposed by van Genuchten (1980). The hydraulic conductivity functions shown in Fig. 6 were defined using the water retention curve parameters and the saturated hydraulic conductivity $\left(k_{s}\right)$ values obtained from flexible wall permeameter tests for both the clay and the sand. The geotextile saturated hydraulic conductivity was based on the permittivity measurement as supplied by the geocomposite manufacturer. The results in Fig. 6 indicate that as suction increases, the hydraulic conductivity values of the three materials decrease at different rates.

The $k$-functions in Fig. 6 indicate that a capillary break is likely at the interface between the clay and the nonwoven geotextile, as well as between the sand and the clay. While suction at an interface between two materials is the same, Fig. 6 highlights that the three tested materials may have different hydraulic conductivities for a given value of suction, except when their curves intersect. Specifically, in vertical, downward flow through an initially dry (high suction) horizontally layered system, a capillary break will occur when the underlying layer has significantly lower hydraulic conductivity than the overlying layer. Water will not flow into the lower layer until the suction decreases to the value at which the conductivity of both layers is the same. This is the case for the interface between the clay and the sand or between the clay and the geotextile component of the geosynthetic drainage layer. Fig. 5 indicates that as suctions increase from 1 to $10 \mathrm{kPa}$, the geotextile and sand become highly unsaturated while the clay maintains a high degree of saturation. Likewise, Fig. 6 indicates that the hydraulic conductivity values of the geotextile and sand decrease sharply with increasing suction, while that of the

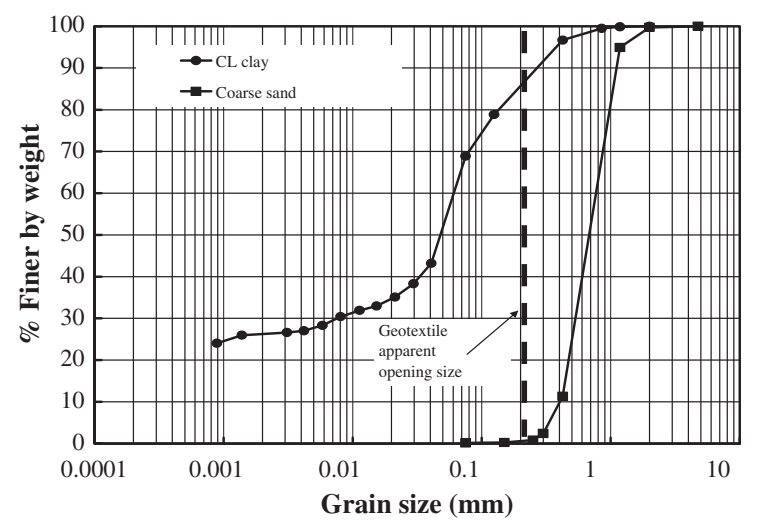

Fig. 4. Comparison between the clay and sand grain size distributions with the apparent opening size of a nonwoven geotextile. 


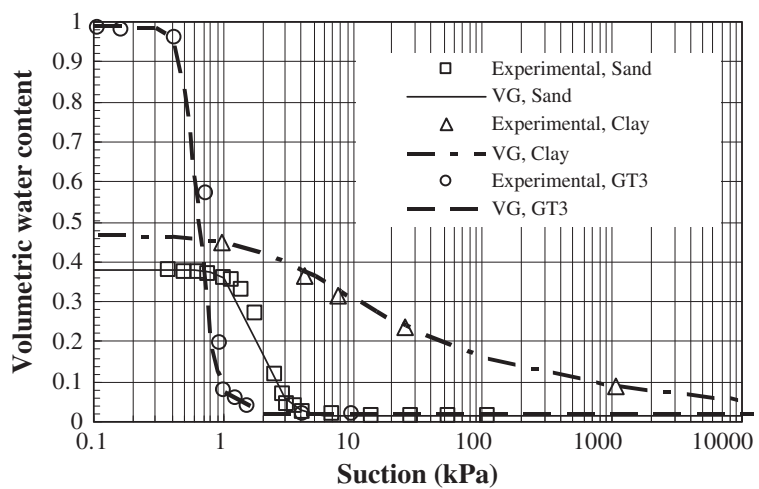

Fig. 5. Water retention curves for soils and geocomposites (note: VG= van Genuchten equation).

silt decreases more gently, intersecting the other two curves at suctions of about 1 and $4.5 \mathrm{kPa}$, respectively.

\subsection{Practical implication: capillary break phenomenon}

Geosynthetic drainage layers are increasingly used as alternatives to conventional sand or gravel drains in landfills, roadway subgrades, mechanically stabilized walls, and dams. The geosynthetic drainage layer configuration consists of a geonet for drainage sandwiched between nonwoven geotextile filters. The in-plane flow through geotextiles and geonets can be reasonably defined if the soil overlying the geosynthetic drainage layer is saturated. However, the overlying soil is often under unsaturated conditions and, in this case, a capillary break may develop within the soil layer, as discussed in the previous section. Understanding of this mechanism is relevant in aspects such as quantification of the impinging flow used in the design of drainage layers, performance evaluation of systems used for quantifying percolation through alternative landfill covers, and interpretation of the information gathered in leak detection systems. Consequently, nonwoven geotextiles and drainage geocomposites were evaluated experimentally using infiltration tests involving geosynthetic-soil columns and compared to infiltrations tests in clay-sand columns (McCartney et al., 2005).

A capillary break is evidenced as a cease in movement of the wetting front (the depth to which water has infiltrated), and storage in the overlying material of moisture in excess of the amount that would be stored when draining under gravity. When a critical suction is reached, the conductivity of the two materials reaches the same value, and water breaks through the interface. This critical suction is referred to as the breakthrough suction.

In order to quantify the unsaturated interaction between conventional and geosynthetic drainage layers with low hydraulic conductivity

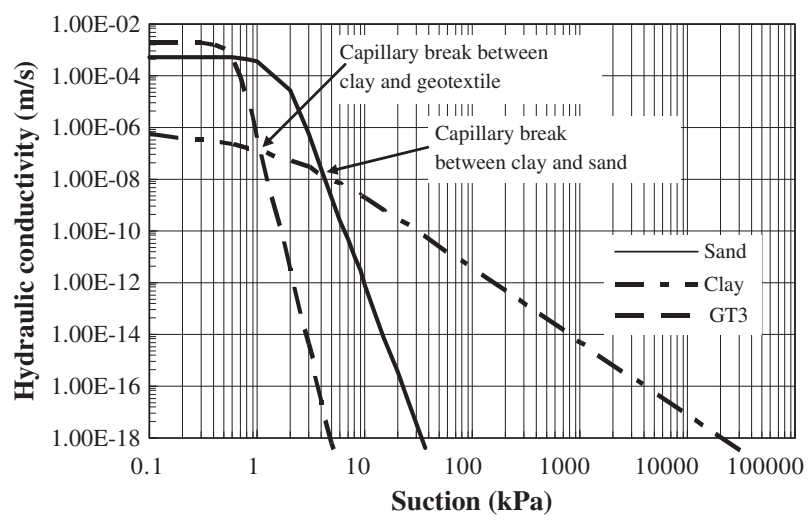

Fig. 6. Predicted hydraulic conductivity functions ( $k$-functions) of soils and geocomposites. soils, geosynthetic-soil profiles were constructed using different soil and geosynthetic materials horizontally layered in cylindrical tubes with a relatively large diameter $(20 \mathrm{~cm})$. Fig. 7 shows a schematic view of two profiles that have been tested as part of the work reported by McCartney et al. (2005) and Zornberg et al. (2010). Column 1 includes a conventional drainage layer, consisting of clay placed over a sand layer. A $150 \mathrm{~mm}$ layer of sand was pluviated to reach the target relative density of 50\%. A $300 \mathrm{~mm}$ layer of clay was placed in $50 \mathrm{~mm}$ lifts over the sand layer using static compaction to the target dry unit weight of $75 \%$ of the maximum dry unit weight based on the standard proctor and a gravimetric moisture content of $8 \%$ (volumetric moisture content of $12 \%$ ). Profile 2 includes a geosynthetic drainage layer involving clay placed over a geocomposite, which in turn rests on a gravel foundation layer. A $300 \mathrm{~mm}$ clay layer was placed in $50 \mathrm{~mm}$ lifts using the same procedures as for Profile 1. Volumetric moisture content values were continuously measured throughout the vertical soil profiles using time domain reflectometry technology (TDR). Fig. 7 shows the location of the TDR probes in both columns. In Column 1, four TDR probes were used. Probes were placed $2 \mathrm{~cm}$ above and below the interface between the clay and the sand to measure the behaviour at the interface. In Column 2, three probes were used; including a probe located $2 \mathrm{~cm}$ above the geocomposite. A peristaltic pump was used to apply a relatively constant flow rate of $0.4 \mathrm{~cm}^{3} / \mathrm{s}$ to the top surface of the clay. This corresponds to a Darcian velocity of $2.06 \times 10^{-7} \mathrm{~m} / \mathrm{s}$. The flow rate was selected to be less than the saturated hydraulic conductivity of the clay to ensure unsaturated conditions.

Fig. 8 shows the change in water content at four depths in profile 1 (Column 1). This figure indicates that the sand is initially very dry, at a volumetric moisture content of approximately 5\%. At this moisture content, the sand has low hydraulic conductivity. The clay soil is initially at a volumetric moisture content of approximately $12 \%$ throughout the entire thickness of the profile. The volumetric moisture content measured by TDR 1 (near the soil surface) increases to approximately $25 \%$ as the moisture front advances through the clay. Similarly, the volumetric moisture content measured by TDR 2 increases to $25 \%$ after a period of about $5000 \mathrm{~min}$. The volumetric moisture content measured by TDR 3 increases to $25 \%$, similar to TDRs 1 and 2. However, TDR 3 shows a continued increase in moisture content to approximately $38 \%$. Also, after approximately 7000 min TDR 2 begins to show an increase in a similar fashion as TDR 3. This behaviour suggests that the wetting front reached the sand interface, but moisture accumulated above the interface instead of flowing directly into the sand layer. After the clay reached a volumetric moisture content of $38 \%$ at the interface, the volumetric moisture content in the sand layer measured by TDR 4 increased rapidly to $26 \%$. The timing of the increase in volumetric moisture content in the sand layer was

Column $1 \quad$ Elevation $(\mathrm{cm}) \quad$ Column 2
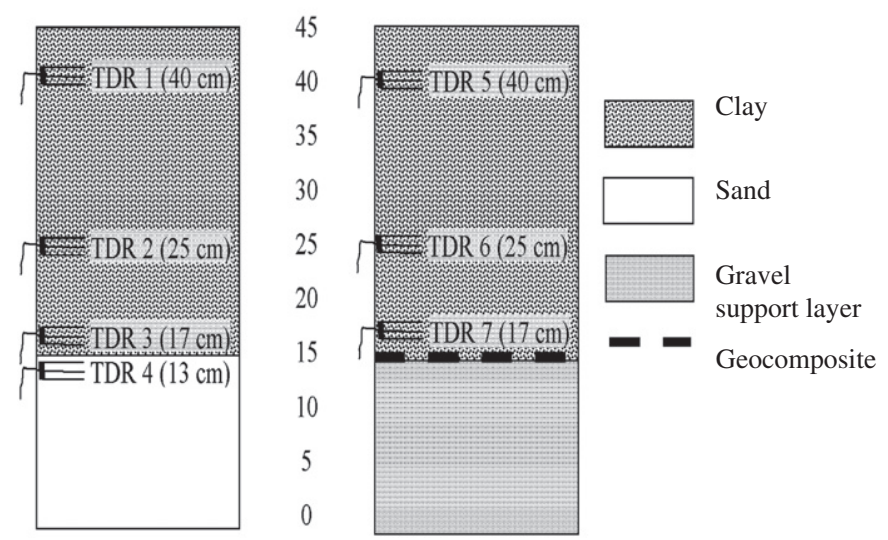

Fig. 7. Schematic view of infiltration columns. 


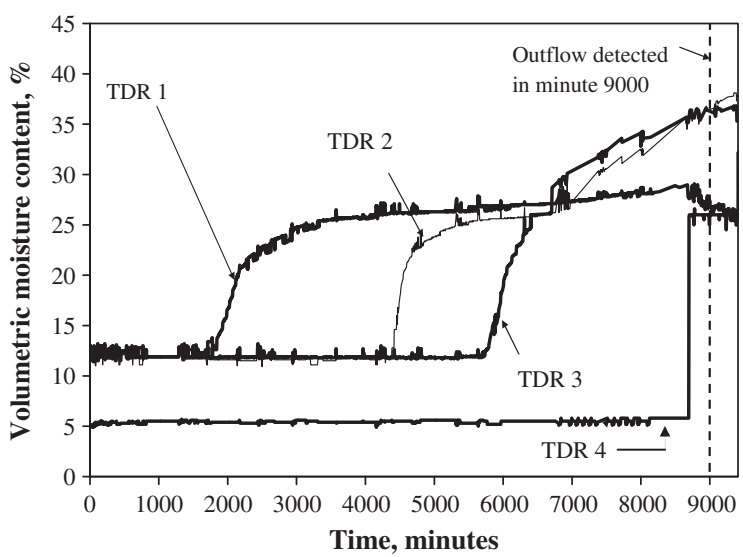

Fig. 8. Volumetric moisture content with depth in Column 1.

consistent with the collection of outflow at the base of the profile, which occurred after approximately $9000 \mathrm{~min}$. The performance of profile 1 is consistent with the development of a capillary break, and indicates that the clay layer has a volumetric moisture content of approximately $36 \%$ at breakthrough. The clay water retention curve shown in Fig. 5 indicates that this volumetric water content corresponds to a suction of approximately $5 \mathrm{kPa}$. This suction is consistent with the breakthrough suction value at which the $k$-functions of the clay and sand intersect, as shown in Fig. 6.

Fig. 9 shows the change in volumetric water content at three depths in the clay in profile 2 (Column 2). Although similar behaviour as profile 1 is noted, the wetting front progresses faster through profile 2 . This is because of a clog that was noted in the water supply tube to Profile 1 after the first 300 min of testing. However, comparison between the two profiles is still possible. The volumetric moisture content in the clay in profile 2 is $12 \%$ at the beginning of testing. The volumetric moisture content recorded by TDR 5 (near the soil surface) increases to approximately 25\% after 2000 min. After approximately $3500 \mathrm{~min}$, the volumetric moisture content measured by TDR 6 also increases to approximately 25\%. Unlike the other two TDRs, the volumetric moisture content measured by TDR 7 (near the geocomposite) shows a continued increase in moisture content to approximately $40 \%$. After TDR 7 shows an increase in volumetric moisture content, the volumetric moisture content recorded by TDRs 5 and 6 also increase from 25 to 40\%. This behaviour suggests that a capillary break and storage of water over the geosynthetic interface also occurs in profile 2 . Outflow from profile 2 was detected after $8180 \mathrm{~min}$, indicating that the breakthrough of the capillary break occurred at a volumetric moisture content of approximately $40 \%$. The clay water retention curve shown in Fig. 5 indicates that this corresponds to a suction of about $3 \mathrm{kPa}$. This suction value is

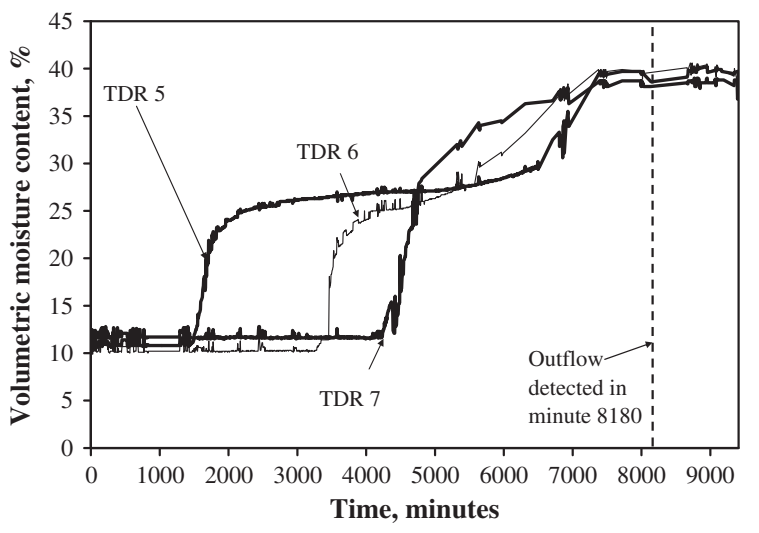

Fig. 9. Volumetric moisture content with depth in Column 2. consistent with the intersection of the $k$-functions for the clay and the geotextile given in Fig. 6 .

The results in Figs. 8 and 9 indicate that similar behaviour can be expected from both conventional granular drains and geosynthetic drainage layers overlain by unsaturated soil. The moisture front advance was indicated by an increase in volumetric moisture content within the profile to approximately $25 \%$ (the moisture content associated with the impinging flow rate). However, as the wetting front reached the interfaces, the unsaturated drainage material created a barrier to flow, and water accumulated above the interfaces as indicated by an increase in volumetric moisture content to values ranging from 35 to $40 \%$. Further, the soil above the interface began to store water to a height of at least $250 \mathrm{~mm}$, indicated by an increase in volumetric moisture content measured by upper TDRs from $25 \%$ to approximately 35 to $40 \%$. Although suction was not monitored, the shape of the water retention curve for the clay indicates that the suction can change significantly with small changes in moisture content near saturation. Accordingly, even though moisture remained relatively constant above the interface about 1000 min before breakthrough in both profiles, the suction was likely decreasing.

The above findings were implemented in the design and construction of alternative covers for the Rocky Mountain Arsenal, a Superfund site located near Denver, Colorado (USA). In particular, nonwoven geotextiles were utilized as capillary barrier material underlying a fine grained unsaturated soil layer (see Williams et al., 2010, 2011; Zornberg et al., 2010).

\section{Unsaturated behaviour of geosynthetic clay liners}

Waste containment facilities form part of critical infrastructure that provides essential community services. In many global population centres this vital infrastructure is designed to ensure negligible long-term environmental and human health impact. To achieve these aims, construction is required of barrier systems which effectively separate the waste and the associated leachate and biogas from the groundwater system and the atmosphere, respectively. One conventional approach to barrier systems has been to construct a "resistive barrier" composed of a capping liner that reduces water ingress into the facility and controls biogas escape into the atmosphere, as well as base liner having a low saturated hydraulic conductivity which minimises leachate migration out of the facility. Over the past two decades, geosynthetic clay liners (GCLs) have become one of the dominant construction materials in waste containment facilities and have gained widespread acceptance for use in liner systems, (Bouazza, 2002; Rowe, 2005; Bouazza and Bowders, 2010). GCLs are typically comprised of a thin layer of bentonite sandwiched between two layers of geotextile with the components being held together by needle-punching or stitch bonding (Figure 10). The primary function of the bentonite layer in a GCL is to create impedance to the flow of migrating liquids (e.g., water), dissolved chemical species and gases or vapours (Gates et al., 2009). This is achieved by its very low permeability when it is fully hydrated after the GCL placement, from the underlying or overlying soil.

However, these GCLs may be subjected to variable hydration states both during initial hydration (since they are typically constructed at a low moisture content and need to be hydrated to moisture content in excess of $100 \%$ to function adequately as a barrier to fluids), during thermal cycles, such as may occur during wet-dry cycles or if exposed to solar radiation, and elevated temperatures at the base liner which can be caused by the degradation of municipal solid waste (Rowe and Hoor, 2009; Bouazza et al., 2011) or mining liquors (Hornsey et al., 2010). Hence, understanding of their water potential is essential to ensure their long term durability under adverse conditions. As a fundamental constitutive relationship, a water retention curve (WRC) can be used to examine their unsaturated behaviour. 

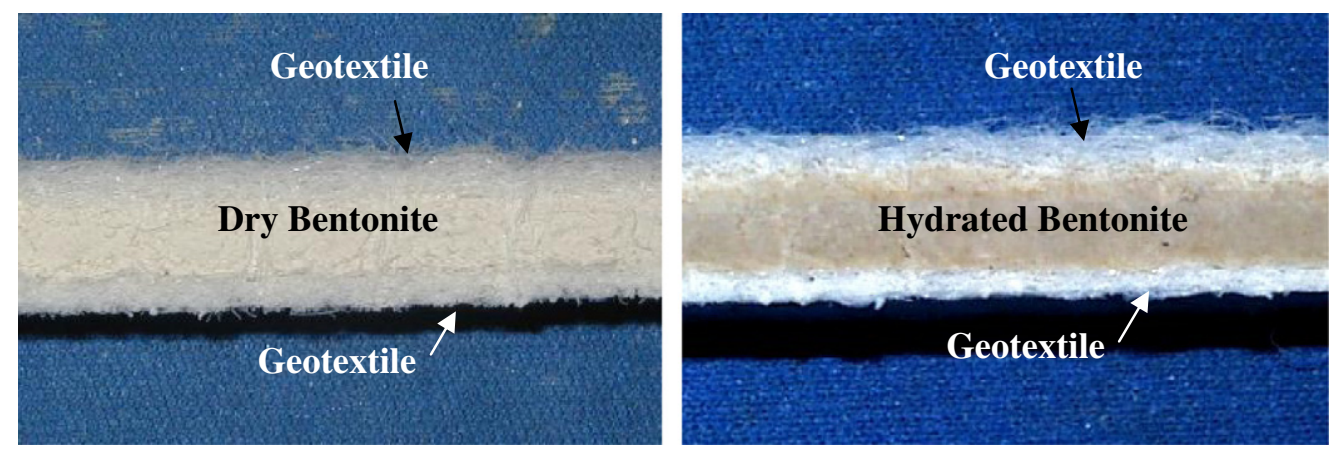

Fig. 10. Geosynthetic clay liner under dry and fully hydrated conditions.

A limited number of studies have been carried out over the last decade, on water retention behaviour of GCLs using different suction measurement techniques. As the key component of GCL, the bentonite represents the strongest influence on the WRC. Generally, one suction measurement method cannot cover the entire WRC curve, due to limits in the accuracy of each method. Different direct and indirect suction measurement techniques have been used alone or in various combinations to gain GCL WRC in previous studies. Daniel et al. (1993) used a vapour equilibrium technique (VET). Barroso et al. (2006) used a filter paper method and obtained reasonable agreement with the results of Daniel et al. (1993). Southen and Rowe (2007) used a pressure plate and pressure membrane extractors to assess the relationship between the degree of saturation and suction in GCLs for a range of suctions between 10 and $10,000 \mathrm{kPa}$. They also examined the effect of overburden pressure together with the relationship between suction and bulk GCL void ratio.

Beddoe et al. (2010) combined high capacity tensiometer (HCT) with capacitive relative humidity sensor measurements to measure the WRC of a GCL. They used a $500 \mathrm{kPa}$ high air entry value (HAEV) porous stone HCT to measure low suction range (up to $500 \mathrm{kPa}$ ) and used the capacitive relative humidity sensor for the range of $10,000 \mathrm{kPa}$ to $350,000 \mathrm{kPa}$. Their results could not cover the range between $500 \mathrm{kPa}$ to $10,000 \mathrm{kPa}$.

The complexity of GCL, with its geotextile-bentonite-geotextile sandwich pattern, in comparison with a uniform material makes measurement and interpretation of WRC complex. Therefore, the point of measurement, quality of measurement and device-sample contact were investigated in previous studies from the perspective of obtaining the WRC of the whole material rather than just the geosynthetic or the bentonite component. Barroso et al. (2006) investigated the effect of filter paper position in relation to the GCL using the filter paper test. They concluded that the filter paper position does not influence GCL suction measurement between gravimetric water contents of $10 \%$ and $115 \%$. Unlike Barroso et al. (2006), the study by Southen and Rowe (2007) which used an axis translation technique, had considerably large scatter because of loose contact between GCL sample and porous filter. Beddoe et al. (2010) installed HCT into the bentonite part of a GLC to avoid contact problems during measurement. Abuel-Naga and Bouazza (2010) recommended a new modified triaxial apparatus which allowed control of the wetting path water content using an attached needle system in the conventional cap. They adopted a silica gel desiccator cell system presented by Lourenco et al. (2007) for drying path measurements. The new triaxial system combined dual suction measurement techniques of thermocouple psychrometer and a relative humidity sensor.

Fig. 11 presents a compilation of the volumetric water content against suction for different type of GCLs on the wetting path from Abuel Naga and Bouazza (2010) and Beddoe et al. (2011). GCL 2 specimen tested by Beddoe et al. (2011) is a thermally treated needle punched GCL with a scrim reinforced nonwoven geotextile as the carrier (material beneath the bentonite) and a nonwoven cover geotextile. It is similar to the GCL specimen tested by Abuel Naga and Bouazza (2010). GCL 1 is a similar product but with a woven geotextile as a carrier.

The measurements in Fig. 11 indicate that the similar GCLs have lower water uptake capacity compared to GCL1. The lower water uptake capacity can be attributed to their internal structure (thermally treated and scrim reinforced) thus restricting their swelling potential. The slight difference in water uptake observed at higher suctions levels ( $>10,000 \mathrm{kPa}$ ) between the two similar GCLs can be attributed to the confining stresses applied during the water retention tests ( $2 \mathrm{kPa}$ for GCL 2 and $50 \mathrm{kPa}$ for the GCL specimen tested by Abuel Naga and Bouazza (2010)). It is expected that a higher confining stress will restrict the GCL swelling potential further leading potentially to different water retention behaviour at lower suctions. Based on the above, one can conclude that the method of manufacture governs the unsaturated behaviour of GCLs. However, further work is needed to investigate the effect of the bentonite components of GCLs especially in terms of mineralogy and grain size.

From a practical view point, understanding the unsaturated behaviour of GCLs and the factors that control it will lead to much better prediction of their response when subjected to conditions involving thermal cycles, solar heating and wet-dry cycles typically encountered in waste containment facilities.

\subsection{Practical implications: potential desiccation of GCLs}

Landfill monitoring has shown that the heat generated by municipal solid waste, can significantly increase the temperature on the underlying landfill liner. Recent data indicate that landfill liner temperature can be expected to reach $30-45{ }^{\circ} \mathrm{C}$ under normal landfill operations (Rowe, 2005; Yesiller et al., 2005; Koerner and Koerner, 2006). With recirculation of leachate, the liner temperature tends to increase faster than under normal operating conditions (Koerner and Koerner, 2006). Higher temperatures (up to $70^{\circ} \mathrm{C}$ ) may also occur at the base of landfills if there is a significant leachate mound

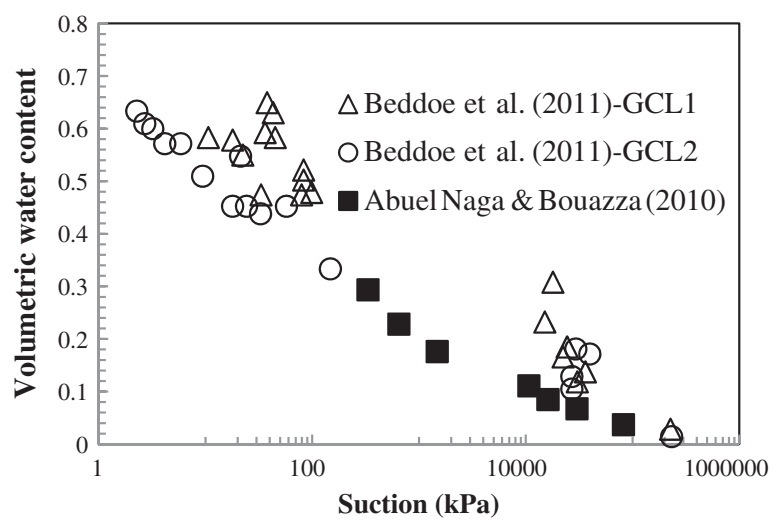

Fig. 11. Water retention of GCLs under wetting path. 
(Yoshida et al., 1996). However, high temperatures (55 to $60{ }^{\circ} \mathrm{C}$ ) were also observed in landfills without leachate mounding (Lefebvre et al., 2000) or in landfills where organic waste was predominant (Bouazza, et al., 2011). Elevated temperatures are also present in lined mining facilities (e.g., heap leach pads, liquors ponds, etc.) due to the processes involved in extracting the different metals (Bouazza, 2010; Hornsey et al., 2010). Often the base barrier systems involve a composite barrier comprised of a geomembrane and either a compacted clay liner or a geosynthetic clay liner (GCL) with a low hydraulic conductivity. One potential consequence of the presence of elevated temperatures is the development of thermal gradients across the liner towards the cooler subgrade soil. A schematic of the conditions existing at the base of a containment facility where for example a GCL is used in combination with a geomembrane is shown in Fig. 12. The presence of a thermal gradient can create a risk of outward moisture movement and possible desiccation of the GCL. The situation is exacerbated by the presence of an overlying geomembrane preventing rehydration of the GCL with moisture from above.

Vapour migration through geomaterials is an important thermohydraulic coupling and critical to understanding the thermo-hydraulic behaviour of the majority of geoenvironmental engineering problems when temperature gradients are apparent such as in the case shown in Fig. 12. This aspect has been recently assessed for an evaporation pond lined with a composite liner similar to the one shown in Fig. 12. The pond is filled with saline water, at temperature up to $70{ }^{\circ} \mathrm{C}$. It is lined with a composite liner consisting of a geomembrane and a geosynthetic clay liner resting on a fine grained subgrade. The GCL was installed at moisture content as received (i.e., GCL relatively dry) and the subgrade was compacted at optimum moisture content $+2 \%$. The groundwater is relatively deep. The scenario modelled assumed the filling of the pond to take place as soon as its construction was completed. The case (Figure 13) was analysed using a transient finite element code COMPASS (Code for Modelling Partially Saturated Soil) developed at the University of Cardiff, U.K. (Thomas and Li, 1997; Thomas and Cleall, 1999). The governing equations for COMPASS are formulated from the primary variables, pore-water pressure, $\mathrm{u}_{\mathrm{l}}$, temperature, $\mathrm{T}$, pore-air pressure, $\mathrm{u}_{\mathrm{a}}$, displacement, $\mathrm{u}$, to describe the thermo-hydromechanical behaviour. In general terms the flow variables are formed into governing equations by consideration of the conservation of mass/energy and the mechanical formulation is formed by consideration of stress equilibrium, with more details of the THM model found in Thomas and He (1994) and Singh (2007). Pseudo 1D axisymmetric numerical analyses have been performed to investigate the heat transfer and moisture movement across the profile, shown in Fig. 13, representing field conditions encountered at the site of the pond. A zero heat flux boundary condition was applied to the side of the domain. The water retention properties of the different materials were assessed in the laboratory.

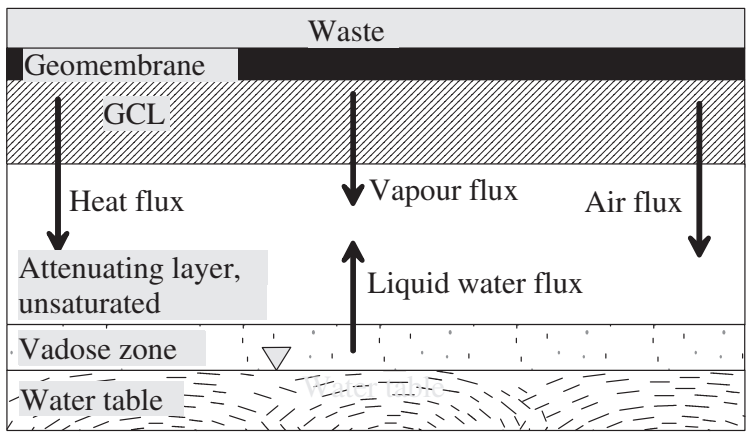

Fig. 12. Thermally induced multiphase fluid transport processes within and beneath a composite liner.

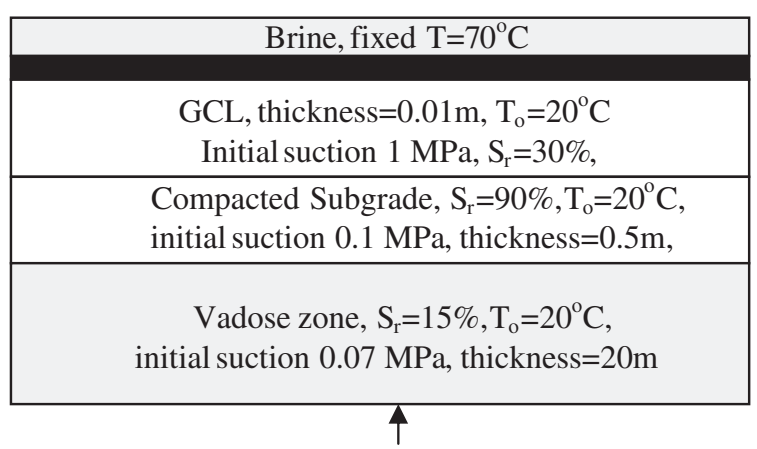

Fixed $\mathrm{T}=20^{\circ} \mathrm{C}$

Fig. 13. Cross section of composite liner and soil profile for an evaporative pond.

Fig. 14 presents the variation of the degree of saturation across the liner and the subsoil. It can be observed that the degree of saturation in the GCL (lower part at $0.0095 \mathrm{~m}$ ) increases rapidly at the beginning due to its higher suction compared to the subgrade suction. However, it peaked at around 55\% (reached within 27 days) indicating that the GCL reached only a partially hydrated state. The upper and the central parts of the GCL reached even lower degrees of saturation. Obviously with heat being present from the start of the filling process and rapidly reaching steady state, hydration of the whole GCL is not optimised since it is subjected to high temperatures from the start of the hydration process (Figure 15). A softening of the saturation, after the peak value was reached, is observed with a steady decrease occurring due to moisture being driven away by heat. The degree of saturation in the subgrade decreased from the beginning to the end of the simulation ( 10 years representing the design life of the pond). Initially moisture has been absorbed by the GCL to assist in its hydration then this was followed by the effect of the heat acting on the liner reaching steady state very quickly as indicated in Fig. 15. The top layers of the vadose zone (within $5 \mathrm{~m}$ ) experienced an increase in the degree of saturation due to moisture migrating from the GCL and the subgrade up to the stage where temperature started increase steeply, with temperatures reaching steady state moisture loses stated to take place leading to a softening of the saturation variation. Bottom layers of the vadose zone have continuous increase of moisture with time because they are being fed with the water from the top layers.

The modelling indicates very clearly that the operation of the pond needs to be carefully planned to allow full hydration of the GCL to take place. There is a need to provide a time lag between completion of the construction of the pond and start of the filling process with saline water at elevated temperatures. Failure to do so will result

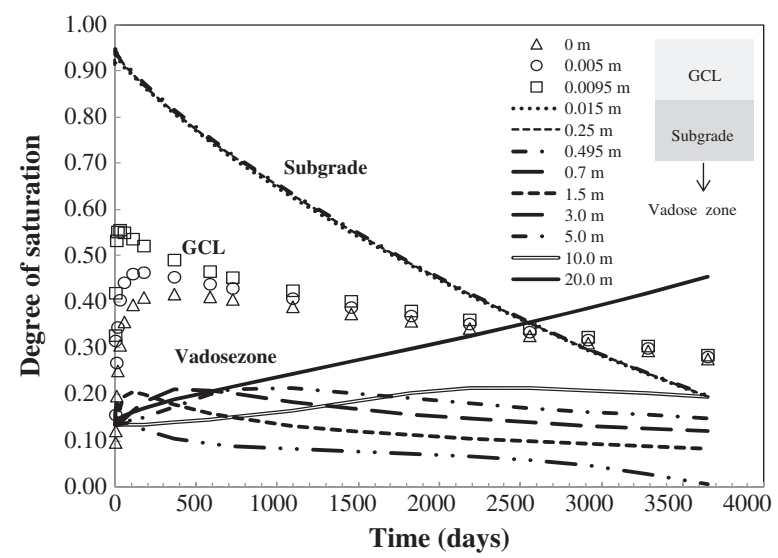

Fig. 14. Degree of saturation variation with time for a GCL, subgrade, and underlying soils. 
in potential desiccation of the GCL which could be detrimental to the longevity of the pond.

\section{Unsaturated soil-geosynthetic interface shear strength}

Waste containment cover or basal liner systems are often composed of several layers of geosynthetics and natural soils. They must not only provide a sound hydraulic/gas barrier but must also be structurally stable during all phases of a project (i.e., during construction, operation, and closure). The interfaces between the different material layers composing a multi-layered lining system often represent potential slip surfaces that need to be considered in slope stability analyses. The shear strengths of these interfaces are assessed by conducting shear tests on the interfaces using direct shear box tests. In most cases these parameters are measured under watersaturated (wet) or air-saturated (dry) conditions. Therefore, they are expressed in terms of total normal stresses rather than effective normal stresses at the interface. Typically, the soil component of a multi layered liner is unsaturated under normal working conditions (i.e., clay liner is installed at optimum moisture content at degree of saturation ranging between 80 and 90\%). Therefore, the initial suction and its change during shearing might have an influence on the final value of the interface shear strength.

It is well known in unsaturated soil mechanics that matric suction plays an important role in the inter-particle or effective stress state in unsaturated soils (Bishop, 1959; Blight, 1967; Fredlund and Morgenstern, 1977; Khalili et al., 2004; Lu and Likos, 2006; Nuth and Laloui, 2008; Lu et al., 2010). An increase in effective stress in unsaturated soils can lead to significant improvements in engineering properties including shear strength and stiffness of soils ( $\mathrm{Lu}$ and Likos, 2006) and soil-geosynthetic interaction (Hamid and Miller, 2009).

The definition of effective stress in unsaturated soils has been a topic of some debate over the past 50 years. While the use of two independent stress-state variables proposed by Fredlund and Morgenstern (1977) has led to some success in fitting constitutive models to experimental data, this approach has received criticism because it cannot be reconciled with classical saturated soil mechanics (Khalili et al., 2004; Nuth and Laloui, 2008) and may require addition parameters to represent changes in strength (Gan et al., 1988; Vanapalli, 2009). Bishop (1959) developed one of the first equations to represent the effective stress $\sigma^{\prime}$ in unsaturated soils:

$\sigma^{\prime}=\left(\sigma-u_{a}\right)+\chi\left(\mathrm{u}_{\mathrm{a}}-\mathrm{u}_{\mathrm{w}}\right)$

where $\sigma$ is the total stress, $\mathrm{u}_{\mathrm{a}}$ is the pore air pressure, $\mathrm{u}_{\mathrm{w}}$ is the pore water pressure, and $\chi$ is the effective stress parameter. The value of $\chi$ has been defined as the degree of saturation (Oberg and Sallfors, 1997; Nuth and Laloui, 2008), as an empirical relationship incorporating the air entry suction (Khalili and Khabbaz, 1998), and the effective saturation (Vanapalli et al., 1996; Lu et al., 2010). Although the definition of effective stress by Bishop (1959) initially received criticism because the role of matric suction in the effective stress varies with the degree of saturation (Blight, 1967) and in predicting collapse (Jennings and Burland, 1962), several recent studies have proposed practical ways to define the single-value effective stress variable (Khalili et al., 2004; Lu and Likos, 2006; Nuth and Laloui, 2008) and shown that it can be used to represent shear strength (Khalili and Khabbaz, 1998; Lu and Likos, 2006) and predict collapse (Khalili et al., 2004). A recent development in the equation for the effective stress was made by Lu et al. (2010), who assumed that Bishop's $\chi$ factor was equal to the effective saturation, which permits integration of the water retention curve into Eq. (2).

$\sigma^{\prime}=\left(\sigma-\mathrm{u}_{\mathrm{a}}\right)+\frac{\left(\mathrm{u}_{\mathrm{a}}-\mathrm{u}_{\mathrm{w}}\right)}{\left(1+\left[\alpha\left(\mathrm{u}_{\mathrm{a}}-\mathrm{u}_{\mathrm{w}}\right)\right]^{\mathrm{n}}\right)^{(\mathrm{n}-1) / \mathrm{n}}}$

where $\alpha$ and $\mathrm{n}$ are the van Genuchten SWRC parameters. This equation is valid when the matric suction is greater or equal to zero, and otherwise reduces to Terzaghi's definition of effective stress for saturated conditions $\left(\sigma^{\prime}=\sigma-\mathrm{u}_{\mathrm{w}}\right)$. Lu et al. (2010) found that Eq. (3) can be used to interpret the shear strength of both unsaturated and saturated soils presented in the literature. Specifically, the shear strength of unsaturated soils was observed to increase linearly with the effective stress defined using Eq. (3), as follows:

$\tau_{\mathrm{f}}=\mathrm{c}^{\prime}+\left[\left(\sigma-\mathrm{u}_{\mathrm{a}}\right)+\frac{\left(\mathrm{u}_{\mathrm{a}}-\mathrm{u}_{\mathrm{w}}\right)}{\left(1+\left[\alpha\left(\mathrm{u}_{\mathrm{a}}-\mathrm{u}_{\mathrm{w}}\right)\right]^{\mathrm{n}}\right)^{(\mathrm{n}-1) / \mathrm{n}}}\right] \tan \phi^{\prime}$

There have been an extensive number of studies on the shear strength of unsaturated soils (see reviews by Sheng et al., 2009 and Vanapalli, 2009), which have identified that increasing suction leads to an increase in the apparent cohesion up to a certain point. Also, the effective friction angle is not affected by changes in suction. Because of this second observation, Lu et al. (2010) found that the use of Eq. (4) leads to a single failure envelope for saturated and unsaturated soils when interpreted in terms of effective stress defined using Eq. (3).

Different from unsaturated soils, relatively few studies have been performed to evaluate the effects of suction on soil-geosynthetic interface shear strength (Sharma et al., 2007; Hatami et al., 2008; Hamid and Miller, 2009; Khoury et al., 2010). These studies have incorporated a two stress-state variable approach to interpret the

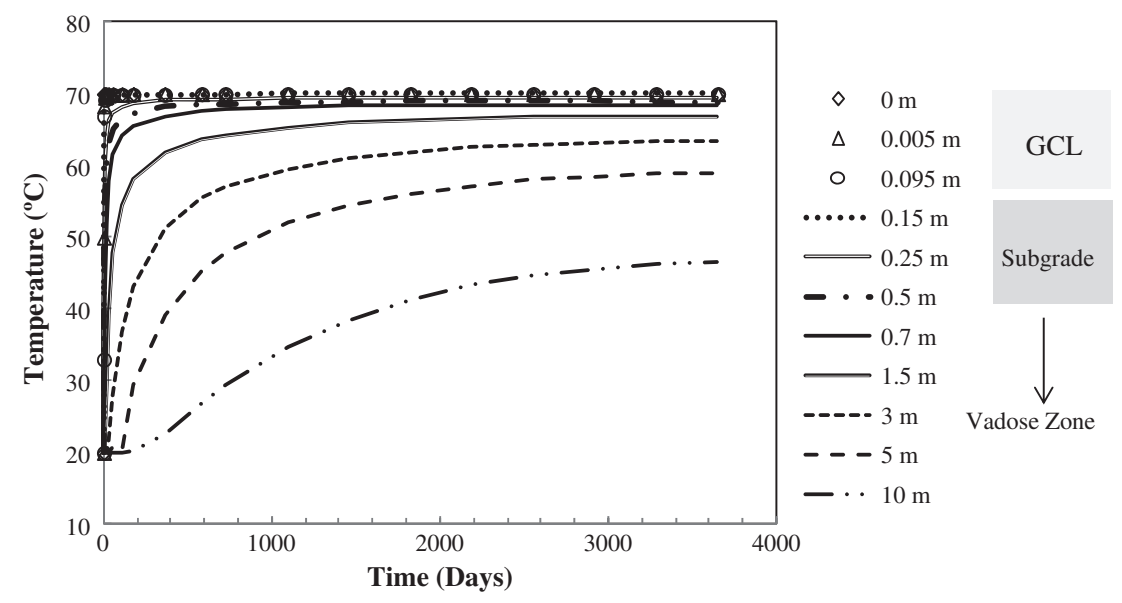

Fig. 15. Temperature variation with time. 
effects of suction on the interface shear strength of soils and geosynthetics. Typical results from a series of direct shear tests performed on unsaturated ML soil specimens as well as the interface between the unsaturated ML soil and a nonwoven geotextile are shown in Fig. 16(a) and (b), respectively. These results show that the friction angles of the ML soil and the ML soil-geotextile interface do not change significantly with matric suction, and that the friction angle of the ML soil-geotextile interface is slightly lower than that of the ML soil, as expected. A clear increase in the cohesion intercept with increasing suction is observed, with a slightly greater increase observed for the ML soil. Although the increase in cohesion of the soil-geosynthetic interface is only $40 \mathrm{kPa}$ for an increase in matric suction from 0 to $100 \mathrm{kPa}$, this increase in cohesion value may have a significant effect on the factor of safety against sliding (and potentially deformation response) for a veneer slope containing a soilgeosynthetic interface, where the total stress is relatively small. A total stress analysis for veneer slope stability or geosynthetic pullout can be performed with the information in Fig. 16(b) (i.e., using the total stress on the geosynthetic interface and incorporating a cohesion intercept to reflect the given value of suction), but this information is not readily incorporated into a flow analysis and a separate constitutive equation to represent the change in cohesion intercept with matric suction is required.

Alternatively, the data in Fig. 16(b) can be reinterpreted using Eq. (4) using the water retention curve of the ML soil, which is shown in Fig. 16(c). In this case, all of the shear strength data points fall onto a single failure envelope shown in Fig. 16(d), which has a slope and intercept that is the same as that observed for saturated conditions in Fig. 16(b). These results indicate that, similar to unsaturated soils, greater effective stress associated with higher suctions leads to an improvement in unsaturated soil-geosynthetic interaction. Because no new parameters are required for the calculation of the shear strength of unsaturated soil-geosynthetic interface shear strength beyond the water retention curve, this approach can be easily combined with a water flow analysis for an earth structure containing geosynthetic reinforcements in order to account for the impact of unsaturated conditions on the soil-geosynthetic interface shear strength on stability or deformation.

\section{Conclusions}

This paper provides an insight into the interaction between soils and geosynthetics under unsaturated conditions and highlights the significance of the unsaturated properties of geosynthetics. The salient conclusions that can be drawn from this paper are:

- The water retention curve of geotextiles shows a highly nonlinear response, with a significant decrease in water content (or degree of saturation) within a comparatively narrow range of suction similar to coarse grained materials.

- The water retention curve of geosynthetic clay liners seems to be dependent on the manufacturing process. However at higher suctions, the bentonite component tends to govern the retention behaviour.

- The hydraulic conductivity of unsaturated geomaterials with relatively large pores such as geotextiles (e.g. gravel, geotextiles) decreases faster than that of fine-grained soils. This phenomenon leads to the counterintuitive situation in which the hydraulic conductivity of unsaturated geotextiles can be significantly smaller than that of fine-grained soils.

- Recent column studies have clearly shown the development of a capillary break at the interface between soils and an underlying nonwoven geotextile. Information from the water retention curve and hydraulic function of the components of a capillary barrier can be used to predict the breakthrough suction and water storage expected in the fine-grained component.
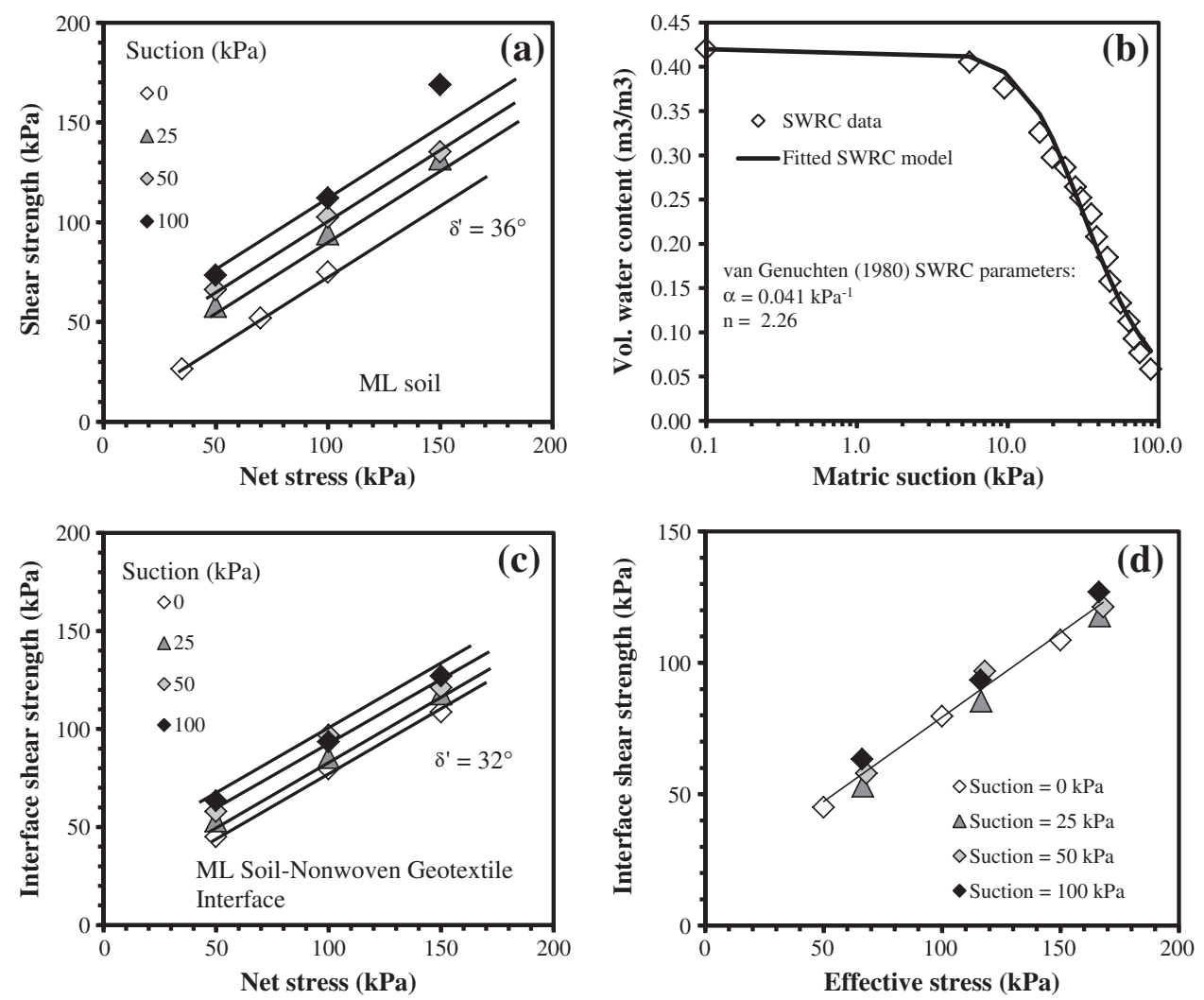

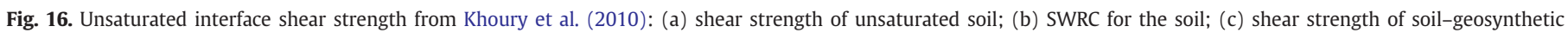
interface;(d) shear strength of soil-geosynthetic interface reinterpreted using Eq. (3). 
- Their capillary break potential behaviour has potential implications on the design of landfill leak detection systems and performance evaluation of alternative cover systems for waste containment facilities.

- The development of geosynthetic capillary barriers may benefit a number of geoenvironmental engineering applications. However, poor performance of earth structures involving nonwoven geotextiles may result from ignoring the capillary break effect.

- The hydration of geosynthetic clay liners depends on the water retention curve of the geosynthetic clay liner.

- The hydraulic performance of geosynthetic clay liners in an engineered liner system subjected to elevated temperatures depends on the water retention curve of the geosynthetic clay liner. This needs to be taken into account in the planning and operation of containment facilities involving heat generated from waste.

- Greater effective stress associated with higher suctions leads to an improvement in soil-geosynthetic interaction.

\section{References}

Abuel-Naga, H., Bouazza, A., 2010. A novel laboratory techniques to determine the water retention curve of geosynthetic clay liners. Geosynthetics International 17 (5), 313-322.

ASTM, 1995. ASTM Standards on Geosynthetics. Sponsored by ASTM Committee D-35 on Geosynthetics, Fourth edition. (178 pp.).

Aydilek, A.H., D'Hondt, D., Holtz, R.D., 2007. Comparative evaluation of geotextile pore sizes using bubble point test and image analysis. Geotechnical Testing Journal 30 (3), 173-181.

Barroso, M., Touze-Foltz, N., Saidi, F.K., 2006. Validation of the Use of Filter Paper Suction Measurements for the Determination of GCL Water Retention Curves. Proceedings of the Eighth International Conference on Geosynthetics, Yokohama, pp. 171-174.

Beddoe, R.A., Take, W.A., Rowe, R.K., 2010. Development of suction measurement techniques to quantify the water retention behaviour of GCLs. Geosynthetics International 17 (5), 301-312.

Beddoe, R.A., Take, W.A., Rowe, R.K., 2011. Water retention of geosynthetic clay liners. Journal of Geotechnical and Geoenvironmental Engineering. http://dx.doi.org/ 10.1061/(ASCE)GT.1943-5606.0000526.

Bishop, A.W., 1959. The Principle of Effective Stress. Teknisk Ukeblad I Samarbeide Med Teknikk, Oslo, Norway, 106(39), pp. 859-863.

Blight, G.E., 1967. Effective stress evaluation for unsaturated soils. Journal of the Soil Mechanics and Foundations Division, ASCE 93, 125-148.

Bouazza, A., 2002. Geosynthetic clay liners. Geotextiles and Geomembranes 20 (1), 3-17.

Bouazza, A., 2010. Geosynthetics in Mining Applications. Proceeding 6th International Congress on Environmental Geotechnics, New Delhi, India, vol.1, pp. 221-259.

Bouazza, A., Bowders Jr., J., 2010. Geosynthetic clay liners for waste containment facilities. CRC Press, Taylor and Francis Group (254 pp.).

Bouazza, A., Zornberg, J., Adam, D., 2002. Geosynthetics in Waste Containments: Recent Advances. Proceedings 7th International Conference on Geosynthetics, Nice, France, vol. 2, pp. 445-507.

Bouazza, A., Freund, M., Nahlawi, H., 2006a. Water retention of nonwoven polyester geotextiles. Polymer Testing 25 (8), 1038-1043.

Bouazza, A., Zornberg, J.G., McCartney, J.S., Nahlawi, H., 2006b. Significance of unsaturated behaviour of geotextiles in earthen structures. Australian Geomechanics Journal 41 (3), 133-142 (September).

Bouazza, A., Nahlawi, H., Aylward, M., 2011. In-situ temperature monitoring in an organic waste landfill cell. Journal of Geotechnical and Geoenvironmental Engineering 137 (12), 1286-1289.

Brooks, R.H., Corey, A.T., 1964. Hydraulic Properties of Porous Medium. Hydrology Paper No. 3.Colorado State University, Fort Collins (March).

Burdine, N.T., 1953. Relative permeability calculations from pore-size distribution data. Petroleum Transactions of the American Institute of Mining and Metallurgical Engineering 198, 71-77.

Daniel, D.E., Shan, H.-Y., Anderson, J.D., 1993. Effects of Partial Wetting on the Performance of the Bentonite Component of a Geosynthetic Clay Liner. Geosynthetics '93,IFAI, St. Paul, MN, 3, pp. 1482-1496.

Fredlund, D.G., Morgenstern, N.R., 1977. Stress state variables for unsaturated soils. Journal of the Geotechnical Engineering Division, ASCE 103 (GT5), 447-466.

Fredlund, D.G., Xing, A., 1994. Equations for the soil-water characteristic curve. Canadian Geotechnical Journal 31, 521-532.

Gan, J.K.M., Fredlund, D.G., Rahardjo, H., 1988. Determination of the shear strength parameters of an unsaturated soil using the direct shear test. Canadian Geotechnical Journal 25, 500-510.

Gates, W.P., Bouazza, A., Churchmann, J., 2009. Bentonite clay keeping pollutants at bay. Elements 5 (2), 105-110.

Hamid, T.B., Miller, G.A., 2009. Shear strength of unsaturated soil interfaces. Canadian Geotechnical Journal 46, 595-606.

Hatami, K., Khoury, C.N., Miller, G.A., 2008. Suction-controlled testing of soil-geotextile interfaces. GeoAmericas, Cancun, Mexico.
Hillel, D., 1998. Environmental Soil Physics. Academic Press0-12-348525-8.

Hornsey, W.P., Scheirs, J., Gates, W.P., Bouazza, A., 2010. The impact of mining solutions/liquors on geosynthetics. Geotextiles and Geomembranes 28 (2), 191-198.

Iryo, T., Rowe, R.K., 2005. Hydraulic behaviour of soil-geocomposite layers in slopes. Geosynthetics International 12 (3), 145-155.

Jennings, J.E.B., Burland, J.B., 1962. Limitations to the use of effective stress in partly saturated soils. Geotechnique 12 (2), 125-144.

Khalili, N., Khabbaz, M.H., 1998. A unique relationship for $\chi$ for the determination of the shear strength of unsaturated soils. Geotechnique 48 (5), 1-7.

Khalili, N., Geiser, F., Blight, G.E., 2004. Effective stress in unsaturated soils, a review with new evidence. International Journal of Geomechanics 4 (2), 115-126.

Khoury, C.N., Miller, G.A., Hatami, K., 2010. Shear Strength of Unsaturated SoilGeotextile Interfaces.GeoFlorida 2010. Advances in Analysis, Modeling and Design GSP, 199, pp. 307-316.

Klute, A., 1986. Water Retention: Laboratory Methods. Methods of Soil Analysis, Part 1: Physical and Mineralogical Methods SSSA. Madison, WI, pp. 635-662.

Koerner, R., 2005. Designing With Geosynthetics, 5th edition. Prentice Hall, NJ.

Koerner, G.R., Koerner, R.M., 2006. Long term temperature monitoring of geomembranes at dry and wet landfills. Geotextiles and Geomembranes 24 (1), 72-77.

Kool, J.B., Parker, J.C., 1987. Development and evaluation of closed-form expression for hysteretic soil hydraulic properties. Water Resources Research 23, 105-114.

Lefebvre, X., Lanini, S., Houi, D., 2000. The role of aerobic activity on refuse temperature rise, I. Landfill experimental study. Journal of Waste Management and Research 18 444-452.

Lourenco, S.D.N., Gallipoli, D., Toll, D., Evans, F., Medero, G., 2007. Discussion: the development of a suction control system for a triaxial apparatus. Geotechnical Testing Journal 30 (4), 1-3.

Lu, N., Likos, W.J., 2006. Suction stress characteristic curve for unsaturated soil. Journal and Geotechnical and Geoenvironmental Engineering 132 (2), 131-142.

Lu, N., Godt, J.W., Wu, D.T., 2010. A closed-form equation for effective stress in unsaturated soil. Water Resources Research 46 (14 pp.).

McCartney, J.S., Kuhn, J.A., Zornberg, J.G., 2005. Geosynthetic Drainage Layers in Contact With Unsaturated Soils. Proceedings 16th International Conference of Soil Mechanics and Geotechnical Engineering, Osaka, Japan, September 12-17, pp. 2301-2305.

Nahlawi, N., 2009. Numerical and experimental investigation of the unsaturated hydraulic behaviour of geotextiles. PhD Thesis, Department of Civil Engineering, Monash University, Australia.

Nahlawi, H., Bouazza, A., Kodikara, J.K., 2007. Characterisation of geotextiles water retention using a modified capillary pressure cell. Geotextiles and Geomembranes 25 (3), 186-193.

Nuth, M., Laloui, L., 2008. Effective stress concept in unsaturated soils: clarification and validation of a unified framework. International Journal for Numerical and Analytical Methods in Geomechanics 32, 771-801.

Oberg, A., Sallfors, G., 1997. Determination of shear strength parameters of unsaturated silts and sands based on the water retention curve. Geotechnical Testing Journal 20 (1), 40-48.

Palmeira, E., Gardoni, M., 2002. Drainage and filtration properties of non-woven geotextiles under confinement using different experimental techniques. Geotextiles and Geomembranes 20, 97-115.

Rowe, R.K., 2005. Long term performance of contaminant barrier systems. Geotechnique 55 (9), 631-678.

Rowe, R.K., Hoor, A., 2009. Predicted temperatures and service lives of secondary geomembrane landfill liners. Geosynthetics International 16 (2), 71-82.

Sharma, J.S., Fleming, I.R., Jogi, M.B., 2007. Measurement of unsaturated soilgeomembrane interface shear strength parameters. Canadian Geotechnical Journal $44,78-88$.

Sheng, D., Zhou, A., Fredlund, D., 2009. Shear strength criteria for unsaturated soils. Geotechnical and Geological Engineering 29 (2), 145-159.

Singh, R.M., 2007. An experimental and numerical investigation of heat and mass movement in unsaturated clays. Ph.D. thesis, Cardiff School of Engineering, Cardiff University, UK.

Southen, J.M., Rowe, R.K., 2007. Evaluation of the water retention curve for geosynthetic clay liners. Geotextiles and Geomembranes 25 (1), 2-9.

Thomas, H.R., Cleall, P.J., 1999. Inclusion of expansive clay behaviour in coupled thermo hydraulic mechanical models. Engineering Geology 54, 93-108.

Thomas, H.R., He, Y., 1994. A coupled heat-moisture transfer theory for deformable unsaturated soil and its algorithmic implementation. International Journal for Numerical Methods in Engineering 40, 3421-3441.

Thomas, H.R., Li, C.L.W., 1997. An assessment of a model of heat and moisture transfer in unsaturated soil. Geotechnique 47 (1), 113-131.

Topp, G.C., Miller, E.E., 1966. Hysteretic water characteristics and hydraulic conductivities for glass-bead media. Proceedings - Soil Science Society of America 30, 156-162.

van Genuchten, M., 1980. A closed-form equation for predicting the hydraulic conductivity of unsaturated soils. Soil Sci. Soc. Am. Proc. 44, 892-898.

Vanapalli, S.K., 2009. Shear Strength of Unsaturated Soils and its Applications in Geotechnical Engineering Practice. 4th Asia-Pacific Conference on Unsaturated Soils. 23-25 November 2009, Newcastle, Australia.

Vanapalli, S.K., Fredlund, D.E., Pufahl, D.E., Clifton, A.W., 1996. Model for the prediction of shear strength with respect to soil suction. Canadian Geotechnical Journal 33, 379-392.

Wang, X., Benson, C.H., 2004. Leak-free pressure plate extractor for the soil water characteristic curve. Geotechnical Testing Journal 27 (2), 1-10.

Williams, L.O., Hoyt, D.L., Hargreaves, G.A., Dwer, S.F., Zornberg, J.G., 2010. Evaluation of a Capillary Barrier at the Rocky Mountain Arsenal. Proceedings 5th International Conference on Unsaturated Soils, Barcelona, Spain, vol. 2, pp. 1431-1436. 
Williams, L.O., Dwyer, S.F., Zornberg, J.G., Hoyt, D.L., Hargreaves, G.A., 2011. Covering it all. Journal of Civil Engineering, ASCE 65-71 (January).

Yesiller, N., Hanson, J.L., Liu, W.L., 2005. Heat generation in municipal solid waste landfills. Journal of Geotechnical and Geoenvironmental Engineering 131 (11), 1330-1344.

Yoshida, H., Hozumi, H., Tanaka, N., 1996. Theoretical Study on Temperature Distribution in a Sanitary Landfill. Proceedings 2nd International Congress on Environmental Geotechnics, Osaka, Japan, 1, pp. 323-328.
Zornberg, J.G., Christopher, B.R., 2007. Chapter 37: Geosynthetics, In: Delleur, Jacques W. (Ed.), The Handbook of Groundwater Engineering, 2nd edition. CRC Press, Taylor and Francis Group, Boca Raton, Florida.

Zornberg, J.G., Bouazza, A., McCartney, J.S., 2010. Geosynthetic capillary barriers: current state of knowledge. Geosynthetics International 17 (5), 273-300. 